\title{
Evaluation of two isoprene emission models for use in a long-range air pollution model
}

\author{
A. Zare ${ }^{1,2}$, J. H. Christensen ${ }^{2}$, P. Irannejad ${ }^{1}$, and J. Brandt ${ }^{2}$ \\ ${ }^{1}$ Institute of Geophysics, University of Tehran, Iran \\ ${ }^{2}$ Department of Environmental Science, Aarhus University, Denmark
}

Correspondence to: A. Zare (aza@dmu.dk)

Received: 29 February 2012 - Published in Atmos. Chem. Phys. Discuss.: 10 April 2012

Revised: 1 August 2012 - Accepted: 2 August 2012 - Published: 16 August 2012

\begin{abstract}
Knowledge about isoprene emissions and concentration distribution is important for chemistry transport models (CTMs), because isoprene acts as a precursor for tropospheric ozone and subsequently affects the atmospheric concentrations of many other atmospheric compounds. Isoprene has a short lifetime, and hence it is very difficult to evaluate its emission estimates against measurements. For this reason, we coupled two isoprene emission models with the Danish Eulerian Hemispheric Model (DEHM), and evaluated the simulated background ozone concentrations based on different models for isoprene emissions. In this research, results of using the two global biogenic emission models; GEIA (Global Emissions Inventory Activity) and MEGAN (the global Model of Emissions of Gases and Aerosols from Nature) are compared and evaluated. The total annual emissions of isoprene for the year 2006 estimated by using MEGAN is $592 \mathrm{Tg} \mathrm{yr}^{-1}$ for an extended area of the Northern Hemisphere, which is $21 \%$ higher than that estimated by using GEIA. The overall feature of the emissions from the two models is quite similar, but differences are found mainly in Africa's savannah and in the southern part of North America. Differences in spatial distribution of emission factors are found to be a key source of these discrepancies. In spite of the short life-time of isoprene, a direct evaluation of isoprene concentrations using the two biogenic emission models in DEHM has been made against available measurements in Europe. Results show an agreement between two models simulations and the measurements in general and that the CTM is able to simulate isoprene concentrations. Additionally, investigation of ozone concentrations resulting from the two biogenic emission models show that isoprene simulated by MEGAN strongly affects the ozone production in
\end{abstract}

the African savannah; the effect is up to $10 \%$ more than that obtained using GEIA. In contrast, the impact of using GEIA is higher in the Amazon region with more than $8 \%$ higher ozone concentrations compared to that of using MEGAN. Comparing the ozone concentrations obtained by DEHM using the two different isoprene models with measurements from Europe and North America, show an agreement on the hourly, mean daily and daily maximum values. However, the average of ozone daily maximum value simulated by using MEGAN is slightly closer to the measured value for the average of all measuring sites in Europe.

\section{Introduction}

Volatile organic compounds (VOCs) are important air pollutants that play a central role in the atmospheric chemistry from urban to the global scale. On a global scale, natural emissions of non-methane VOCs (NMVOCs) largely exceed anthropogenic emissions (Guenther et al., 1995; Olivier et al., 1996). Guenther et al. (1995) estimated the annual global emissions of biogenic non-methane VOCs (BVOCs) to be $1150 \mathrm{TgC}$. This value represents about $90 \%$ of total NMVOC emissions (Lathière et al., 2006). BVOCs react with oxides of nitrogen $\left(\mathrm{NO}_{\mathrm{x}}\right)$ in the presence of solar radiation to form various secondary air pollutants, such as ozone. Ozone is not only a pollutant, toxic for human beings and agricultural crops, but also a potent short-lived greenhouse gas in the troposphere. In addition, formation of secondary organic aerosols (SOA) is a process in which BVOCs play a key role (Tsigaridis and Kanakidou, 2003). Besides causing impacts on human health, SOA act as cloud 
condensation nuclei and influence the radiation balance of the Earth. Among BVOCs, isoprene is the most important species. It is one of the most reactive species with a short atmospheric lifetime of around minutes to hours (Atkinson and Arey, 2003). Moreover, it is the most abundant of BVOCs in the atmosphere (with global annual emissions equal to that of methane around $500 \mathrm{TgC}$ ) (Guenther et al., 1995).

Three dimensional chemistry transport models (CTMs) are used to predict ozone concentrations based on emissions of VOCs and $\mathrm{NO}_{\mathrm{x}}$. These models can also be used to study the impact of BVOC emissions on atmospheric chemistry. BVOC emissions have been incorporated as off-line static emission inventories into CTMs since the mid-1980s. However, coupling of biogenic emission models with CTMs is required in order to study the interactions between CTMs and surface fluxes of BVOCs. Because BVOC emissions are influenced by the surface conditions and weather, generally the coupled system ensures that the BVOC models are forced by the same land-use type and weather as those used in the CTMs.

Guenther et al. (1995) developed the global model GEIA on a 1 degree by 1 degree grid for use in global CTMs. On a regional scale, the Biogenic Emissions Inventory System (BEIS/ BEIS2/ BEIS3) was developed by Pierce et al. (1998). In recent years, a few global-scale models (e.g. LPJ-GUESS by Arneth et al., 2007 and BVOCEM by Lathière et al., 2010) have been introduced to estimate the isoprene emissions with different vegetation and emission algorithms. Among recent models, the new global Model of Emissions of Gases and Aerosols from Nature (MEGAN) was developed as the next generation emission model for biogenic emissions of gases and aerosols. It is suitable for regional modeling as well; due to the high spatial resolution ( $30 \mathrm{~s}$ latitude by $30 \mathrm{~s}$ longitude corresponding to $1 \mathrm{~km}^{2}$ ) database for emission factors (EF) and land cover distribution (Guenther et al., 2006).

During the last decade, several studies have been carried out to investigate the impact of isoprene on tropospheric ozone concentrations by incorporating BVOC models into CTMs (Steiner et al., 2008; Pfister et al., 2008; Bao et al., 2010; Souza et al., 2010). Uncertainties in the isoprene emission inventories, modeling of chemical pathways and ambient $\mathrm{NO}_{\mathrm{x}}$ abundance accompany the modeling studies of isoprene impacts on atmospheric chemistry. For better prediction of the occurrence of atmospheric chemical compounds due to isoprene, particularly of ground-level ozone, it is necessary to implement more accurately calculated emissions from BVOC models in CTMs.

A number of studies have compared the isoprene models before incorporating the modules into CTMs on both global (Arneth et al., 2011) and regional (Wiedinmyer et al., 2008; Lam et al., 2011; Poupkou et al., 2010) scales. Arneth et al. (2011) found agreement in the spatial distribution, interannual variability and total emissions as simulated by the three global isoprene emission models of MEGAN, LPJGUESS and BVOCEM. However, on regional scale, for in- stance, Pouliot and Pierce (2009) demonstrated substantial differences in all components of the isoprene algorithms of BEIS3 and MEGAN, which resulted in $53 \%$ difference in the annual estimates of isoprene emissions over North America.

The main objective is still to implement the emission models into the CTMs to allow the different isoprene emission estimations to be properly evaluated against the measurements while the other parts of CTMs are retained. A number of studies have also been conducted to evaluate results of the integrated MEGAN in air quality models with satellite and/or ground-based observations on the very local scale (Geng et al., 2011; Steiner et al., 2008; Müller et al., 2008). Using MEGAN in different CTMs has provided different results on regional scales against measurements. Baker (2007), for example, shows that using isoprene emissions from MEGAN improves CAMx4 simulation of high ozone episodes in the Midwest of the United States. In contrast, Warneke et al. (2010) find that MEGAN emissions using the transport model FLEXPART are in most cases higher than those determined from the measurements (using isoprene airborne data of the eastern United States). Such studies allow a detailed comparison and evaluation of MEGAN versus observations, but on specific regions.

In the present work, we focus our attention on the comparison and evaluation of GEIA and MEGAN with background ozone measurements, using a long-range air pollution model covering the Northern Hemisphere. Because these two global models have been widely used in air quality models, the importance of evaluating these biogenic algorithms used in CTMs has been recognised.

Over Europe, an algorithm developed based on the GEIA parameterization was compared with a specific model described by Steinbrecher et al. (2009), and evaluated using the CHIMERE CTM model with ground-level ozone observations (Curci et al., 2009). Moreover, Curci et al. (2010) evaluated the performance of MEGAN using CHIMERE for surface concentrations of formaldehyde ( $\mathrm{HCHO}$ ) and isoprene at limited stations in Europe.

Since the CTM model used in this study is a hemispheric model, the emission models can be compared and evaluated on a larger scale, focusing on ground-based ozone in both $\mathrm{Eu}-$ rope and North America. We also evaluate our results against available isoprene measurements from some stations in $\mathrm{Eu}-$ rope. Furthermore, this paper compares the different parts of MEGAN and GEIA algorithms, and focuses on sources of difference as a first step to implement into CTMs.

Section 2 describes the biogenic models and the CTM used in this study. Results of simulations, comparisons and evaluations are presented and discussed in Sect. 3. Section 4 highlights the concluding remarks and an outlook for future studies. 


\section{Model descriptions}

\subsection{The DEHM chemistry-transport model}

The model used in this study is the Danish Eulerian Hemispheric Model (DEHM), which is a 3-D large-scale Eulerian atmospheric chemistry transport model. The model has been applied in several long-range transport air pollution studies, covering most of the Northern Hemisphere from $10^{\circ} \mathrm{S}$ to $90^{\circ} \mathrm{N}$ (see e.g. Christensen, 1997; Hedegaard et al., 2011; Brandt et al., 2012), with a two-way nesting capability to obtain higher resolution over limited areas (Frohn et al., 2002). The model is defined on a polar stereographic projection true at $60^{\circ} \mathrm{N}$ and is here applied with two domains - a mother domain with a resolution of $150 \mathrm{~km} \times 150 \mathrm{~km}$ and a nested domain covering Europe with a resolution of $50 \mathrm{~km} \times 50 \mathrm{~km}$. The model includes 29 irregular vertical layers extending to the $100 \mathrm{hPa}$ pressure level in a sigma-coordinate system. It is designed to simulate both the gaseous and the aerosol phases, presently including 67 different species with 122 chemical reactions.

Most of emissions are derived from a combined dataset, which includes (1) EDGAR2000 Fast track and GEIA with a $1^{\circ} \times 1^{\circ}$ resolution for the Northern Hemispheric domain; and (2) EMEP with a $50 \mathrm{~km} \times 50 \mathrm{~km}$ resolution for Europe. In DEHM, natural emissions from wildfires are included based on Schultz et al. (2008). Natural emissions of $\mathrm{NO}_{\mathrm{x}}$ from soil and lightning and Black Carbon, mainly from biomass burning, are based on the GEIA database. Biogenic emissions of isoprene are described in the following subsection.

The chemical scheme used in DEHM is based on the explicit approach of Strand and Hov (1994). The scheme has been extended by updating several original photolysis as well as the inorganic and organic chemistry rates. Furthermore, several reactions concerning particulate sulphate and a detailed description of the ammonia chemistry have been included to improve the origin chemical scheme in the model. The chemical scheme of isoprene oxidation with $\mathrm{OH}$ and $\mathrm{NO}_{3}$ in DEHM is described by Frohn (2004).

The required meteorological inputs are provided by the mesoscale meteorological model MM5v3.7 (Grell et al., 1994) and defined on the same domains and resolutions as in DEHM. The National Centers for Environmental Prediction (NCEP) Final Analyses (FNL) data $\left(1^{\circ} \times 1^{\circ}\right.$ spatial and $6 \mathrm{~h}$ temporal resolution) have been used to provide the initial and boundary conditions required by the MM5 (http: //dss.ucar.edu/datasets/ds083.2/).

\subsection{Isoprene emission models}

In this section, a brief description of the two BVOC models used in this study is presented and the differences between these isoprene algorithms are summarized.

First, the model that we call GEIA, in this paper, is a NMVOC global emission inventory provided as one of the goals of Global Emissions Inventory Activity and described by Guenther et al. (1995). The algorithm simulates the light and temperature dependency of isoprene emissions and estimates the flux of isoprene from vegetation given by

$F=E D \gamma$

where $E$ is an ecosystem dependent emission factor $\left(\mu \mathrm{gCg} \mathrm{g}^{-1}\right.$ dry mass $\left.\mathrm{h}^{-1}\right)$, which represents the rate of isoprene emission at standard conditions; $D$ is the foliar density (g dry mass $\mathrm{m}^{-2}$ ground); $\gamma$ is a non-dimensional activity factor that takes into account the effects of temperature and photo-synthetically active radiation (PAR) (Guenther et al., 1995). For each grid cell within the model domain, the total flux of isoprene is calculated as the sum of emissions from each ecosystem within that cell. Each area of the Earth's land surface is assigned by one of 59 different ecosystem types with a resolution of $0.5^{\circ} \times 0.5^{\circ}$ that are compiled by Olson (1992).

Alternatively, isoprene emissions have been calculated with the empirical algorithm MEGAN v2.04 that presented by Guenther et al. (2006). MEGAN simulates isoprene emission based on empirical relationships between key drivers and emission as in GEIA, while the model is extended to include more processes that control emissions. The standard conditions for the emission factors in MEGAN include not only air temperature and radiation (as in GEIA), but also leaf area index (LAI), foliage age, solar angle, relative humidity, wind speed, soil moisture, and past weather conditions (Guenther et al., 2006). MEGAN includes, for instance, short- to long-term weather history to account for the seasonal cycle of the emissions. It has also several significant improvements to account for the influences of leaf age, $\mathrm{CO}_{2}$ concentration, soil moisture, and within-canopy variation in light and temperature. Moreover, the model estimates the net emission to the atmosphere and includes a term to account for variations in canopy production and loss of isoprene. This study considers most of these effects (including the impact of soil moisture), but ignores those from $\mathrm{CO}_{2}$ concentrations and loss of isoprene within the canopy. One of the differences between MEGAN and GEIA model is in the treatment of plant species area coverage. In GEIA, plant species are mostly treated explicitly and grouped into 59 different ecosystems, whereas MEGAN uses a suite of six plant functional types (PFTs): broadleaf tree, needle leaf evergreen tree, needle leaf deciduous tree, shrub, crop and grass. In this study, we use the MEGAN v2.04 dataset, which comprises the geographical distribution of both the fractional cover and the standard emission factor of the six PFTs. These parameters as well as the leaf area index were all supplied by the National Center for Atmospheric Research (http://cdp.ucar.edu/). These monthly LAI datasets are used as the driving land cover variables for MEGAN to estimate the response of emissions to temporal variations in leaf age and LAI. Monthly LAI data, averaged over the fraction of 
land area covered by vegetation, is needed for the months of the model simulation and the preceding month.

In this study we have implemented the empirical algorithm PCEEA (the parameterized canopy environment emission activity) into MEGAN to simulate the response of isoprene emission to changes in environmental conditions. The PCEEA algorithm utilizes a different set of equations to estimate the canopy-level of environment emission activity factor. However, the standard detailed canopy environment model calculates leaf-level photosynthetic photon flux density (PPFD) and temperature of sun and shade leaves at each canopy depths.

We have applied the MEGAN and GEIA models with temperature and cloud cover variables generated by MM5v3.7 on the same domain and grid configuration, i.e. the projection and grid size as in DEHM. In order to compare the results of these two BVOC models, the isoprene emissions have been calculated for the last decade (1999-2009). However, here we focus on the year 2006 as an example.

\subsection{Measuring networks}

In order to evaluate the DEHM model performance with different isoprene emission inventories, comparisons have been made using observations of isoprene concentrations in Europe and of ozone concentrations in both Europe and North America. For Europe, the measurements used for this evaluation originates from the EMEP measuring network, which includes a large number of chemical components. Details about the measurement period and the location of the measuring sites are presented in Hedegaard et al. (2008). For the North American domain, the monitoring data of the hourly ozone concentrations are provided by the US Environmental Protection Agency (EPA). The database provides air quality data collected at outdoor monitors across the United States (http://www.epa.gov/airdata/). We selected some of the field campaigns, which have data for each hour in the entire year 2006.

\section{Results}

\subsection{Evaluation of isoprene emissions and driving factors}

The MEGAN and GEIA platforms have been used to estimate grid-based emissions on an hourly time step for an extended area of the Northern Hemispheric for the year 2006. The total annual isoprene emission in the study area (from $10^{\circ} \mathrm{S}$ to $90^{\circ} \mathrm{N}$ ) estimated using MEGAN is $592 \mathrm{Tg} \mathrm{yr}^{-1}$, which is higher than the $487 \mathrm{Tg} \mathrm{yr}^{-1}$ isoprene emission estimated by GEIA. Our estimated emissions are within the range of global values of about $460-770 \mathrm{Tg} \mathrm{yr}^{-1}$ reported in previous studies (Guenther et al., 2006; Arneth et al., 2008; Ashworth et al., 2010). Ashworth et al. (2010) have pointed out that the MEGAN estimates of total annual iso- prene emissions increase with the temporal resolution of the input weather data. Since in this study MEGAN uses hourly weather data derived from original 6-hourly NCEP/FNL dataset, the estimated isoprene emission is close to the higher end of previously reported values.

The spatial distribution of total annual isoprene emissions calculated with MEGAN and GEIA are shown in Fig. 1, together with their absolute differences. Both models estimate the largest isoprene emissions in the tropics. These are obtained from a combination of warm temperatures, high levels of radiation and higher foliar density (Arneth et al., 2011). Temperate regions in the south-eastern United States have high fluxes throughout the summertime. As shown in the figure, the largest difference is around $10 \mathrm{~g} \mathrm{~m}^{-2} \mathrm{yr}^{-1}$ that emerges clearly over tropical regions. MEGAN shows larger isoprene emissions in Africa, while GEIA estimates higher values on South America.

In Fig. 2, daily isoprene emissions are displayed for 2006. Peak emission rates occur in the summer months when the two driving forces, i.e. temperature and solar radiation, are highest. The temporal variations of the simulated emission by the two models follow each other; MEGAN shows the higher values. In summer, the largest discrepancy reaches $15 \%$. Different parameterizations, different land cover data, and/or different emission factors might have contributed to the differences observed between the MEGAN and GEIA estimations. Figure 3 shows the GEIA and MEGAN emission factors; emission rates at standard conditions of $303 \mathrm{~K}$ and $1500 \mu \mathrm{mol} \mathrm{m}^{-2} \mathrm{~s}^{-1}$ at the top of the canopy. In GEIA, all ecosystem types were assigned with one of the five values of emission factors given in Guenther et al. (1995) and summed to estimate the total emission for a location, while MEGAN uses an approach that accounts for geographic variations in the emission factors attributed to each PFT. Comparison of these maps with corresponding emission rates in Fig. 1 indicates that the differences between GEIA and MEGAN are mainly from the use of different base emission factors, especially at lower latitudes. To test this hypothesis, we carried out MEGAN simulations with an alternative emission factor scheme. This alternative assigns a single isoprene $\mathrm{EF}$ for each PFT based on the approach used in GEIA (Fig. 4). This scheme introduces different distributions for both emission factors (Fig. 4a) and emission rates (Fig. 4b) compared to Figs. 3 (top right) and 1 (top right), respectively. It is apparent that even in the same model (MEGAN), the differences between emission rate distributions are mainly due to different corresponding emission factor maps. As Guenther et al. (2006) pointed out, the estimated emissions using a constant emission factor for each PFT (like the approach used in Fig. 4) lead to significant errors; we have used the standard MEGAN emission factor scheme in the following.

To better understand the reason of difference between the two model simulations, Fig. 5 shows the mean annual environment emission activity factor in the study area. The nondimensional emission activity factor estimates the response 


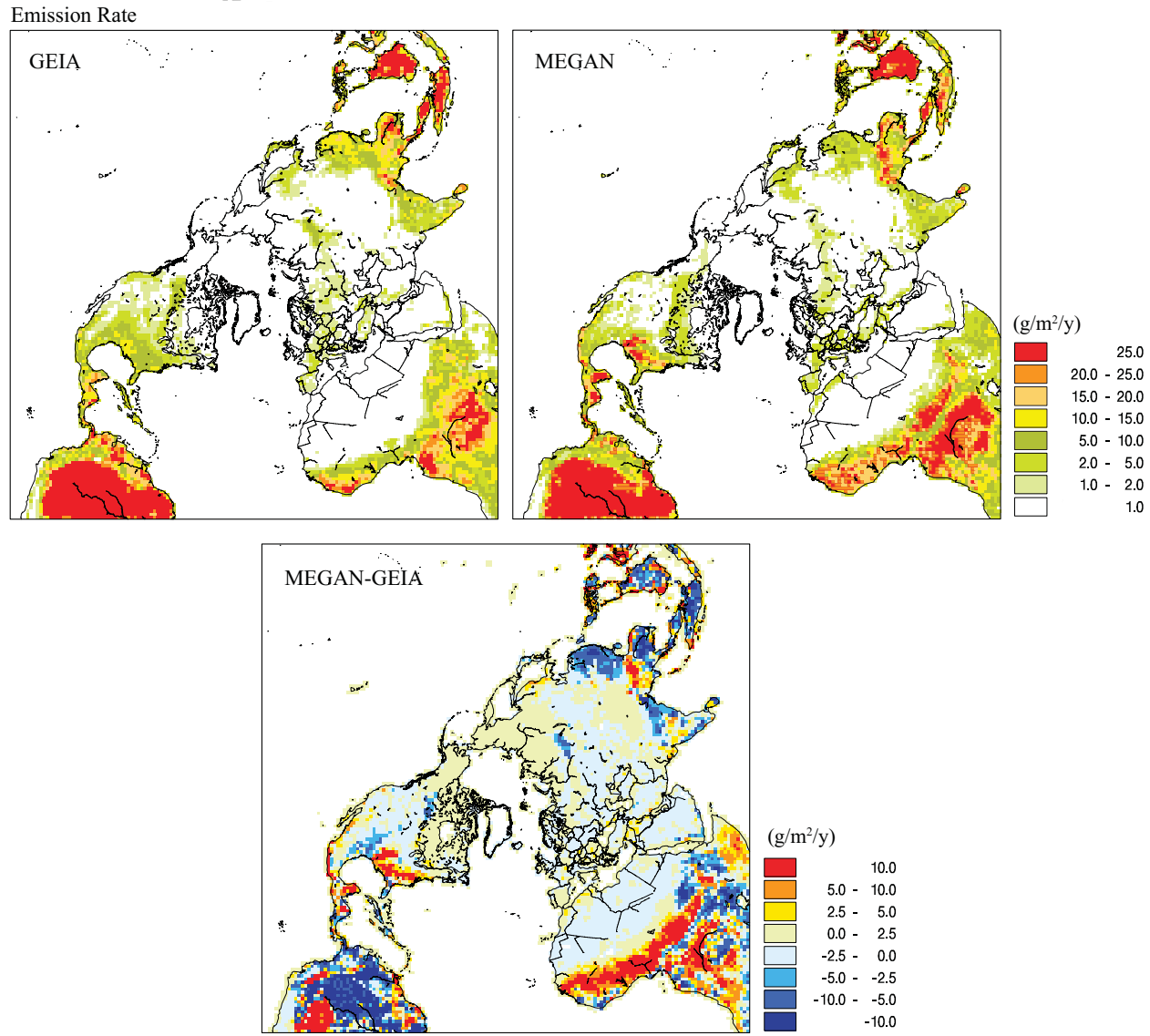

Fig. 1. Spatial distribution of the annual isoprene emission rates ( $g$ isoprene $\mathrm{m}^{-2} \mathrm{yr}^{-1}$ ) calculated with GEIA and MEGAN, together with their difference for 2006.

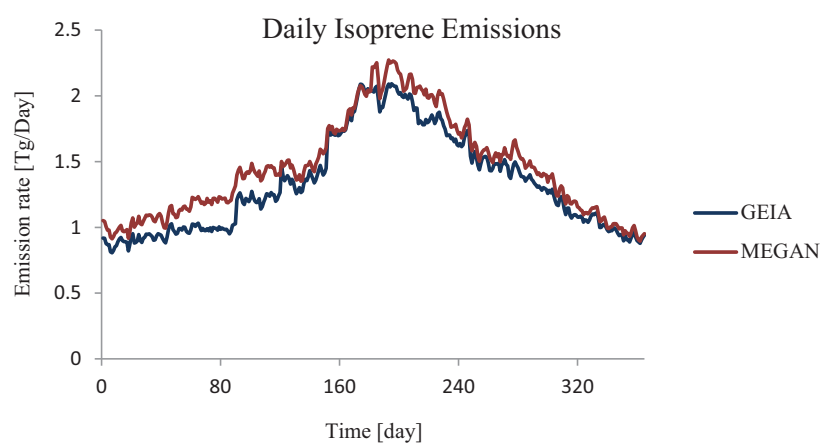

Fig. 2. Daily total isoprene emissions calculated by both GEIA and MEGAN in the study area for 2006.

of isoprene emission to changes in environmental conditions that are equal to unity at standard conditions. The MEGAN PCEEA algorithm described by Eqs. (10) through (15) in Guenther et al. (2006) requires monthly LAI, hourly and daily average air temperature, solar transmission, and PPFD. In Guenther et al. (1995) the light and temperature effects in GEIA are parameterized by Eqs. (9) and (10), and canopy shading effect is parameterized by Eqs. (12) through (16) as a canopy radiative transfer model. As seen in Fig. 5, MEGAN generally shows a larger environment emission activity factor. Considering Figs. 1 and 3, the source of difference in emission rates (Fig. 1) over, for example, tropical Africa originates from the effect of environment activity factor (Fig. 5).

In general, the effects of leaf age and soil moisture on isoprene emission (not shown) are not dominant near the regions where the isoprene emission is high, because leaf age and soil moisture activity factors have high values close to unity. Therefore, the major reason of difference in emission rates from the two models might be due to the emission factors and environment activity factors, respectively. Figure 6 shows the distribution of average isoprene emission rates calculated by the models for summer (JJA) and winter (DJF) in 2006. The discrepancy of the emission rate distributions in the tropical area is more apparent in summer than in winter. MEGAN has a higher sensitivity of isoprene emission to the temperature compared to GEIA (not shown). Figure 7 shows the temperature pattern, used as a driving variable in the emission models, for 2006. The highest temperatures are found over 


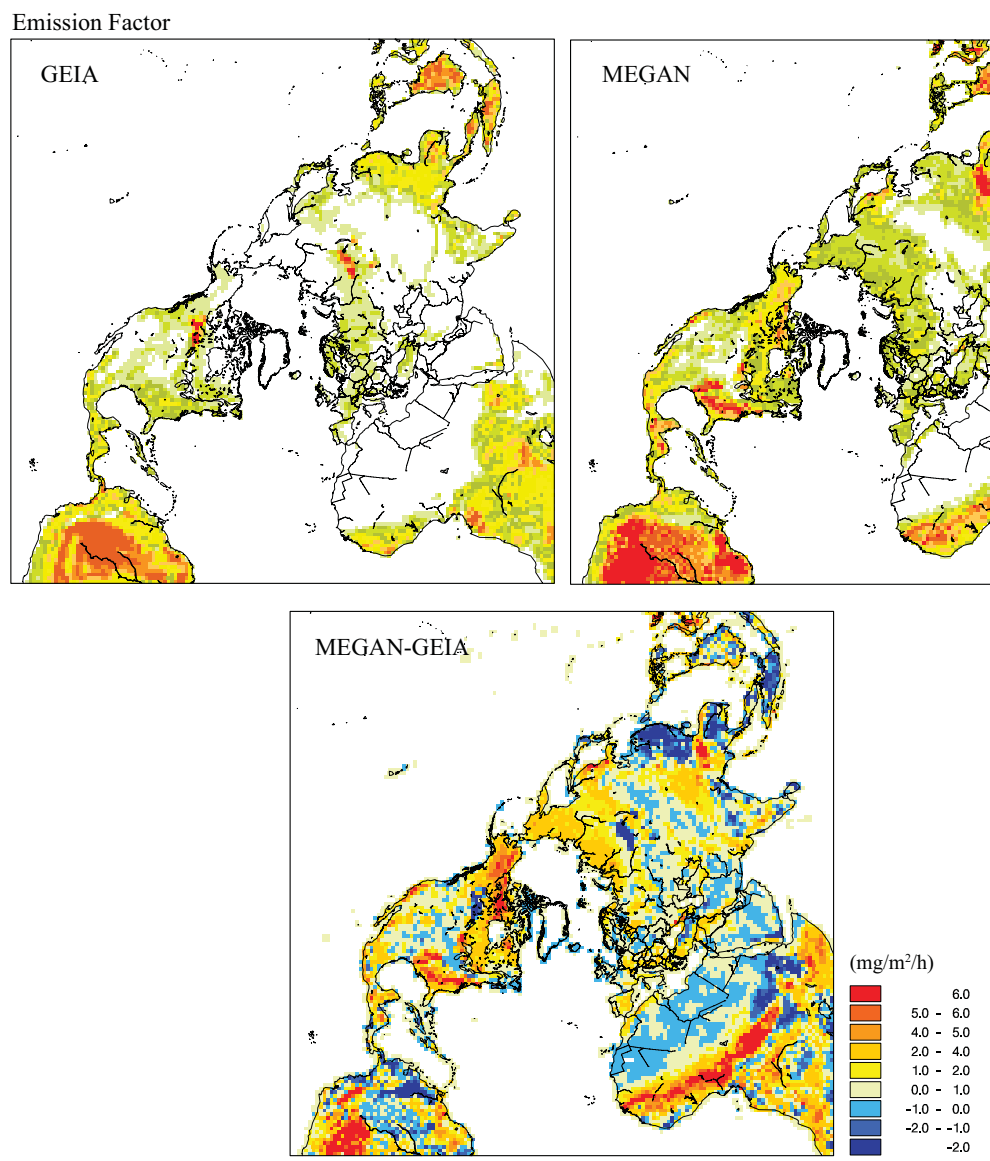

Fig. 3. Spatial variability of isoprene emission factors $\left(\mathrm{mg}\right.$ isoprene $\mathrm{m}^{-2} \mathrm{~h}^{-1}$ ) used in the simulations with the MEGAN and GEIA models, together with their difference.
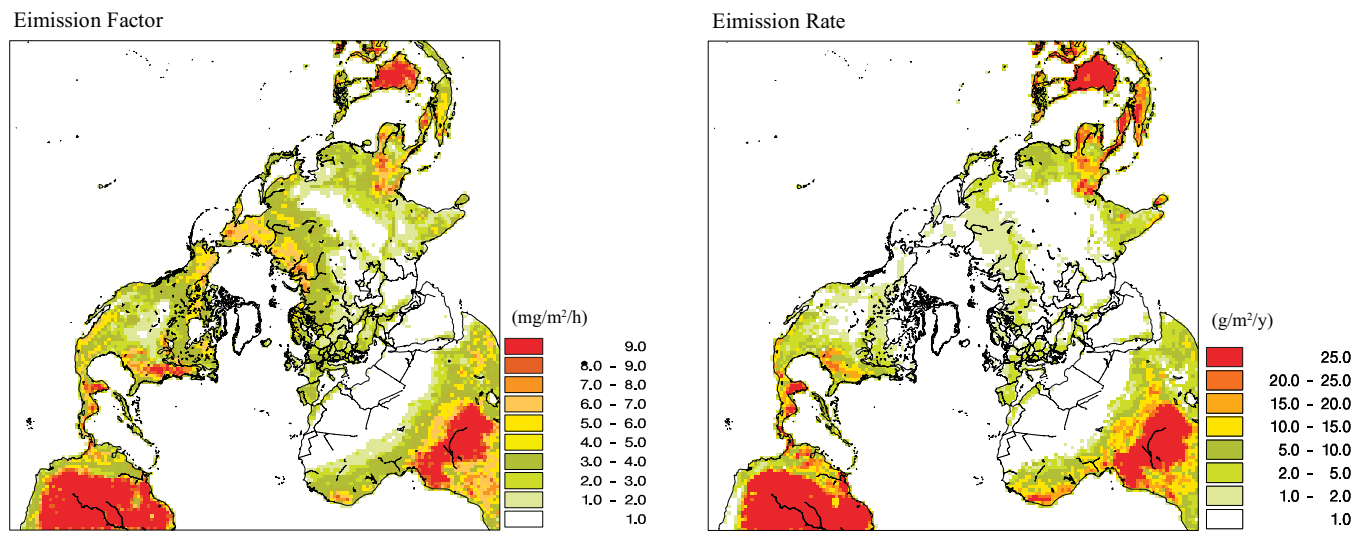

Fig. 4. Distributions of emission rate and its corresponding emission factor as a standard alternative method in MEGAN simulation. The total emission of each location is calculated from sum of a single isoprene EF for each PFT. 

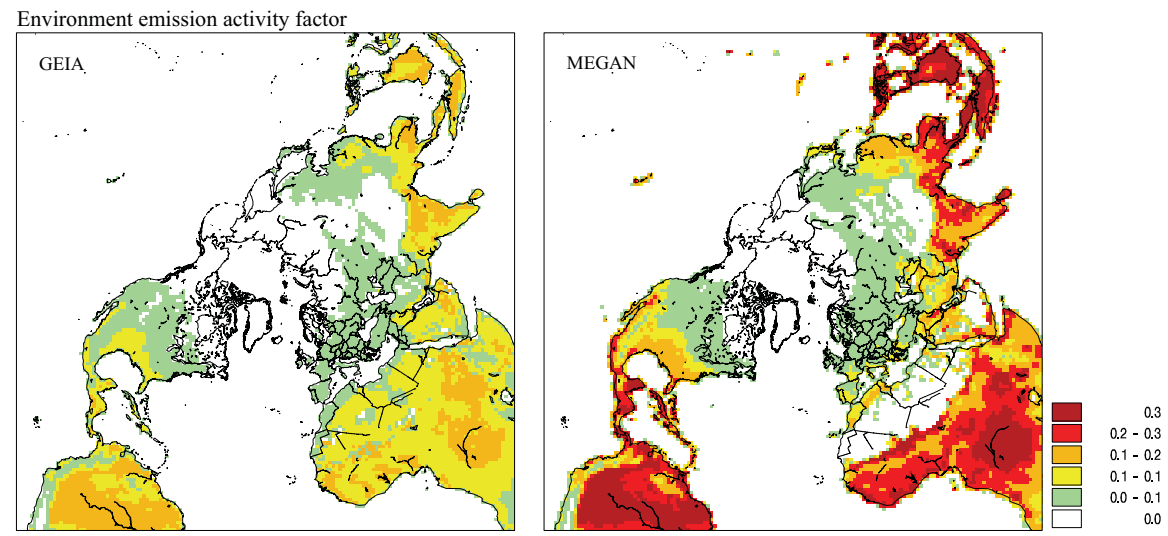

Fig. 5. Non-dimensional environment emission activity factor, calculated for each grid cell based on the equations described by Guenther et al. $(1995,2006)$ for GEIA and MEGAN models, respectively.
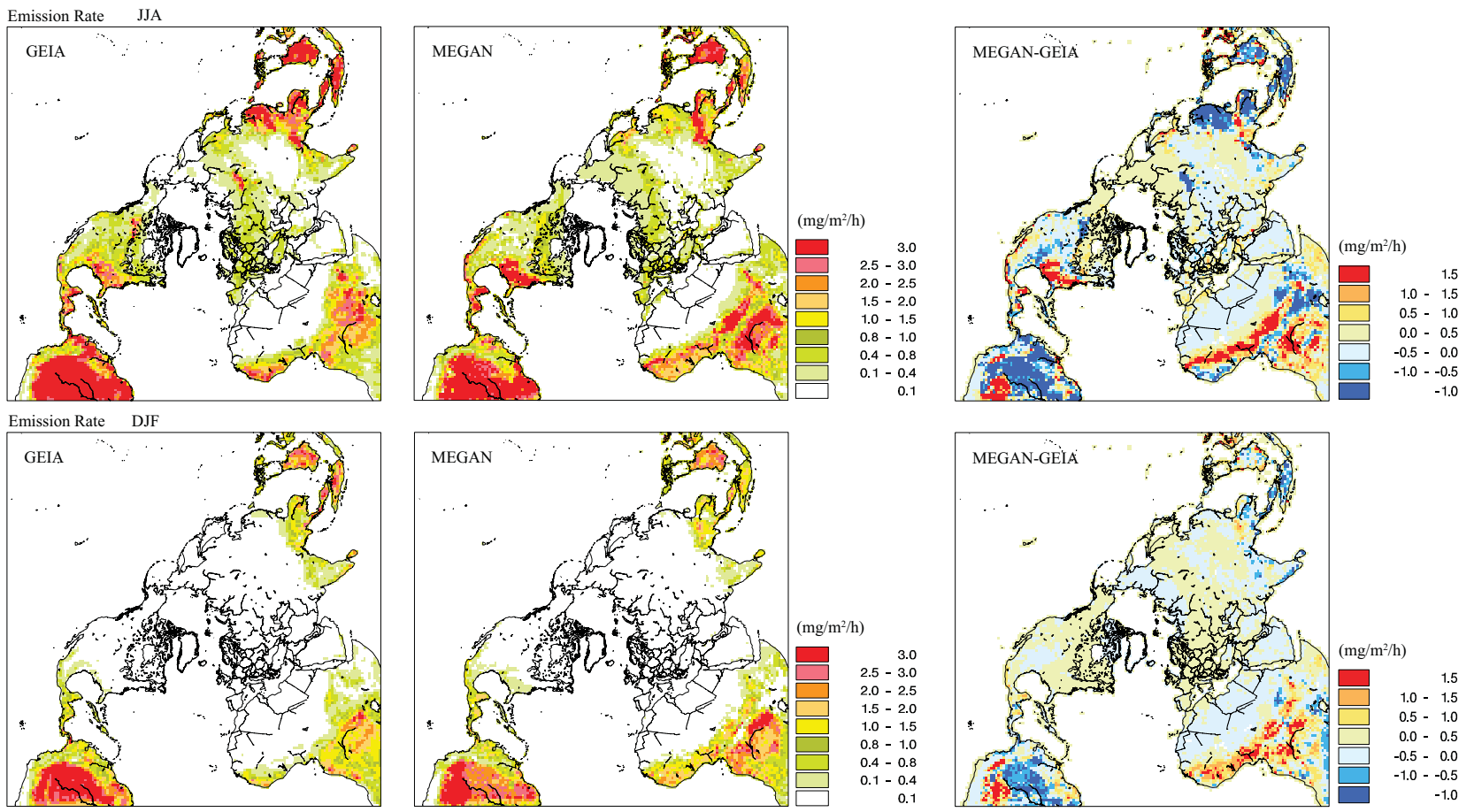

Fig. 6. Seasonal isoprene emission rates, estimated by MEGAN and GEIA together with their differences, for summer (JJA) and winter (DJF), 2006.

the subtropics (e.g. east of the USA) and African Savannah in the summer. This is why MEGAN estimates considerable emissions in the region in the summer.

\subsection{Evaluation of isoprene concentrations}

In this subsection, we present results of implementing MEGAN and GEIA into DEHM for online calculation of the isoprene emissions and evaluation the DEHM simulations with measurements.
Figure 8 shows the spatial distributions of the annual isoprene concentrations in the lowest model layer (around $12 \mathrm{~m}$ ) using MEGAN and GEIA for the year 2006. Due to the short atmospheric lifetime (around $0.5-2 \mathrm{~h}$ ), isoprene cannot be transported far from its sources. Therefore, it is reasonable to assume that the spatial distribution of isoprene concentrations is similar to that of the corresponding emissions. The highest concentrations, with values up to $4 \mathrm{ppbV}$, occur similarly in the tropics, where the largest isoprene emissions have been obtained by both models. However, the additional 


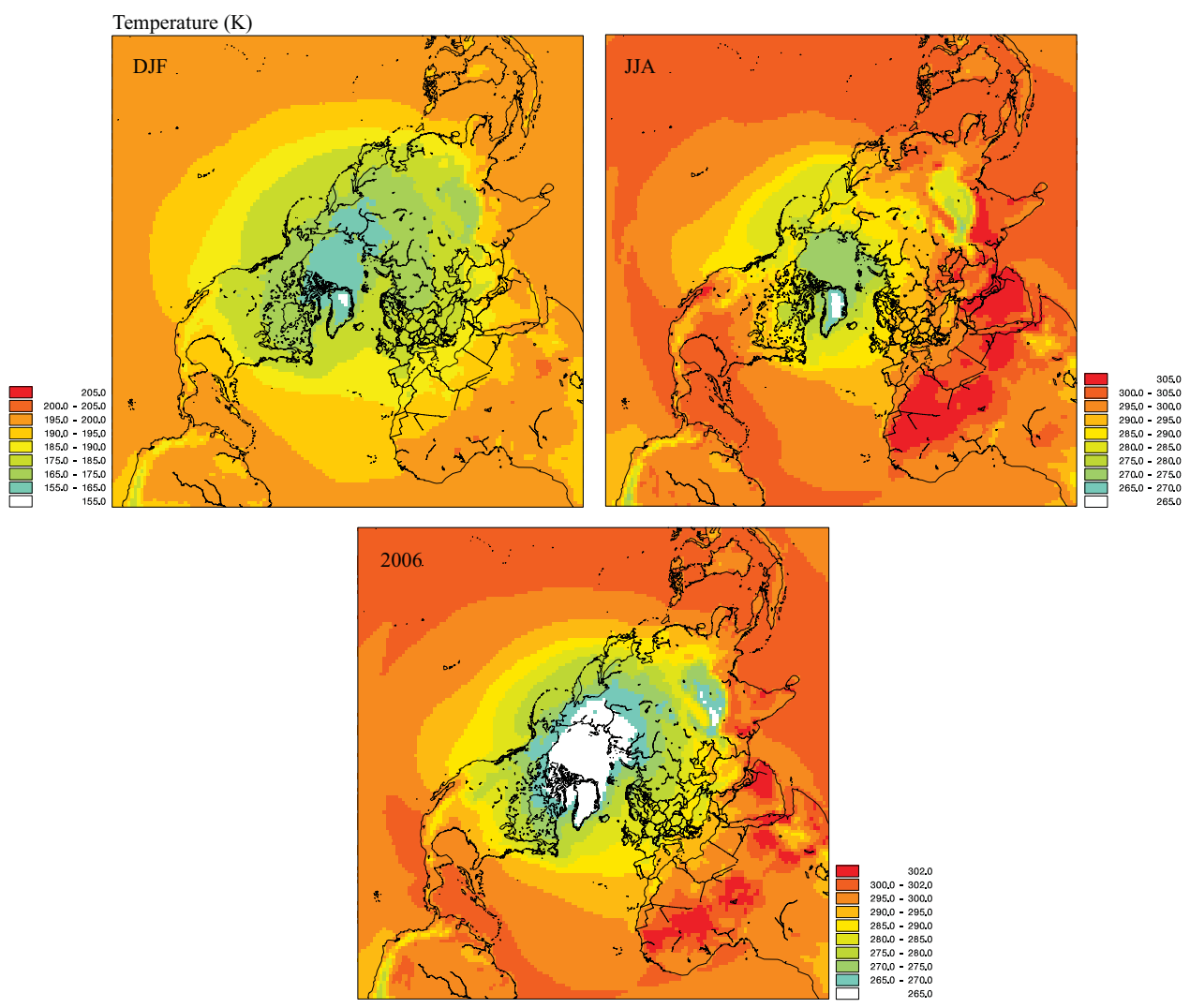

Fig. 7. Mean temperature pattern of the lowest model layer provided by MM5v3.7 in 2006; the entire year, summer (JJA) and winter (DJF).
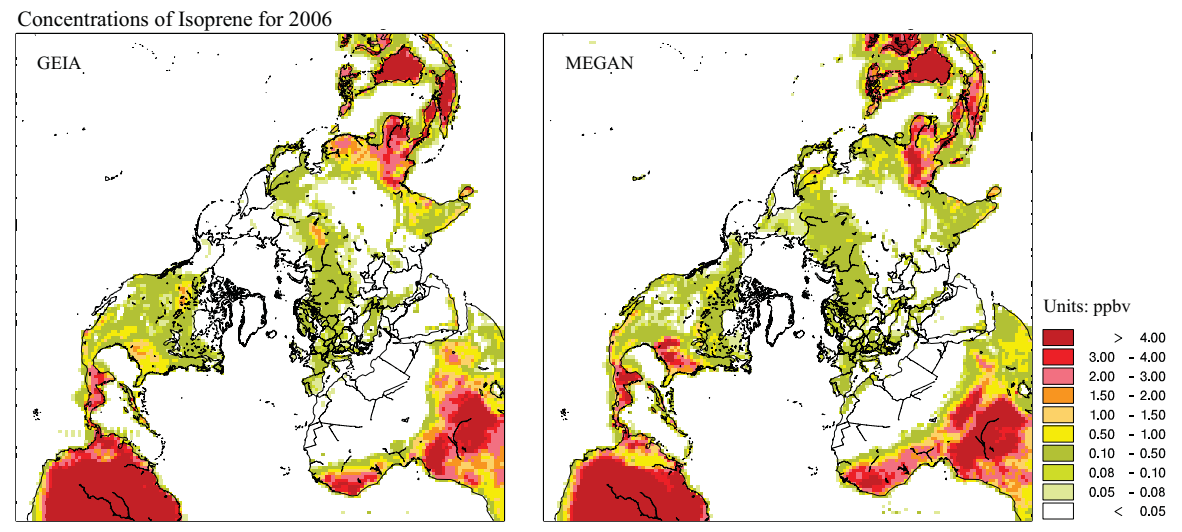

Fig. 8. Annual isoprene concentrations (ppbV) simulated by DEHM in the lowest model layer (with thickness of $12 \mathrm{~m}$ ) using the MEGAN and GEIA biogenic emission models.

isoprene emissions in MEGAN affect the concentrations in, e.g. the African savannah and the south-eastern part of the United States. It is apparent that the discrepancies of the emission distributions result in differences between the isoprene concentration simulations of the two models.

Hourly isoprene concentrations simulated using DEHM are compared with isoprene measurements from the EMEP network (http://www.nilu.no/projects/ccc/emepdata. html). The available observed data for year 2006 are obtained from 9 stations in Europe located in Germany, France, Czech Republic and Switzerland. The number of stations with available isoprene measurements is quite small and cannot constitute the basis for a full scale evaluation. In addition, the data are infrequent, making an accurate analysis and comparison of measurements from the different sites difficult. However, the results can give an indication of whether the model 
Table 1. Comparison of the mean (M) isoprene concentrations between observed and calculated data by DEHM using both biogenic models in 2006. The performance of DEHM based on both GEIA and MEGAN are evaluated using the correlation coefficient and the fractional bias (FB). $H$ is the height of the station above sea-level.

\begin{tabular}{|c|c|c|c|c|c|c|c|c|}
\hline $\begin{array}{l}\text { Country/ } \\
\text { Station }\end{array}$ & $\begin{array}{l}\text { Lat/ } \\
\text { Lon }\end{array}$ & $\begin{array}{l}\text { M_obs } \\
\text { (ppbv) }\end{array}$ & $\begin{array}{l}\text { M_MEGAN } \\
\text { (ppbv) }\end{array}$ & $\begin{array}{l}\text { M_GEIA } \\
(\mathrm{ppbv})\end{array}$ & $\begin{array}{l}\text { Correlation/FB } \\
\text { (MEGAN) }\end{array}$ & $\begin{array}{l}\text { Correlation/FB } \\
\text { (GEIA) }\end{array}$ & $\begin{array}{l}\text { No. } \\
\text { data }\end{array}$ & $\begin{array}{l}H \\
(\mathrm{~m})\end{array}$ \\
\hline Germany/Langenbrugge & $52.48^{\circ} \mathrm{N} / 10.45^{\circ} \mathrm{E}$ & 0.039 & 0.122 & 0.090 & $0.68 / 1.03$ & $0.72 / 0.79$ & 79 & 74 \\
\hline Germany/Schauinsland & $47.54^{\circ} \mathrm{N} / 7.54^{\circ} \mathrm{E}$ & 0.065 & 0.446 & 0.217 & $0.59 / 1.49$ & $0.57 / 1.08$ & 74 & 1205 \\
\hline Germany/Neuglobsow & $53.10^{\circ} \mathrm{N} / 13.02^{\circ} \mathrm{E}$ & 0.104 & 0.113 & 0.096 & $0.79 / 0.09$ & $0.75 /-0.07$ & 78 & 65 \\
\hline Germany/Schmücke & $50.39^{\circ} \mathrm{N} / 10.46^{\circ} \mathrm{E}$ & 0.025 & 0.220 & 0.200 & $0.77 / 1.59$ & $0.88 / 1.56$ & 80 & 937 \\
\hline Germany/Zingst & $54.26^{\circ} \mathrm{N} / 12.44^{\circ} \mathrm{E}$ & 0.124 & 0.153 & 0.056 & $0.70 / 0.21$ & $0.66 /-0.74$ & 79 & 1 \\
\hline France/Donon & $48.30^{\circ} \mathrm{N} / 7.0^{\circ} \mathrm{E}$ & 0.468 & 0.236 & 0.129 & $0.85 /-0.65$ & $0.84 /-1.13$ & 85 & 775 \\
\hline France/Peyrusse Vieille & $47.37^{\circ} \mathrm{N} / 0.10^{\circ} \mathrm{E}$ & 0.690 & 0.065 & 0.111 & $0.55 /-1.65$ & $0.77 /-1.44$ & 59 & 236 \\
\hline Czech Rep./Kosetice & $49.35^{\circ} \mathrm{N} / 15.05^{\circ} \mathrm{E}$ & 0.051 & 0.189 & 0.234 & $0.64 / 1.15$ & $0.69 / 1.28$ & 70 & 633 \\
\hline All & & 0.195 & 0.193 & 0.142 & & & & \\
\hline
\end{tabular}

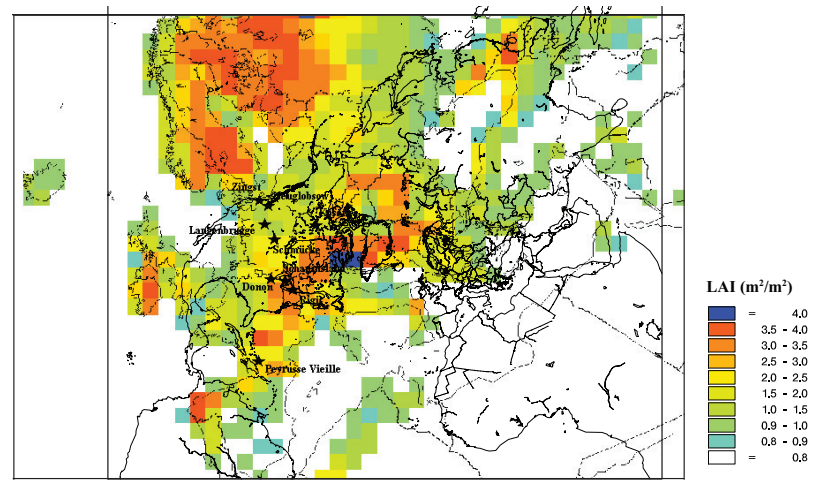

Fig. 9. LAI (Leaf Area Index) emission activity factor from PCEEA MEGAN approach described by Guenther et al. (2006) for the Europe domain. The asterisks show the location of measuring sites from EMEP measuring network studied in Table 1.

simulations are in the right order of magnitude. Also, for one of the stations (Rigi, Switzerland), the time variation can be evaluated. The Rigi station is the only station for which continuous measurements ( 2 hourly) are available whereas the samples were acquired twice a week in other stations.

Table 1 shows the comparison between mean observed and mean simulated isoprene concentrations using GEIA and MEGAN. The statistical comparison for the stations with coarser time resolutions together with the numbers of valid measurements for each station during the study period is shown in the table. The mean isoprene concentrations of the stations based on MEGAN simulations tend to be more consistent with in situ measurements than those based on GEIA. The reported comparison of CHIMERE simulations (using MEGAN) and measurements represents similar tendency for the stations located in France and Czech Republic (Curci et al., 2010). Figure 9 displays location of the stations on a background total LAI activity factor map for summer. In Fig. 10, the measured 2-hourly isoprene concentrations
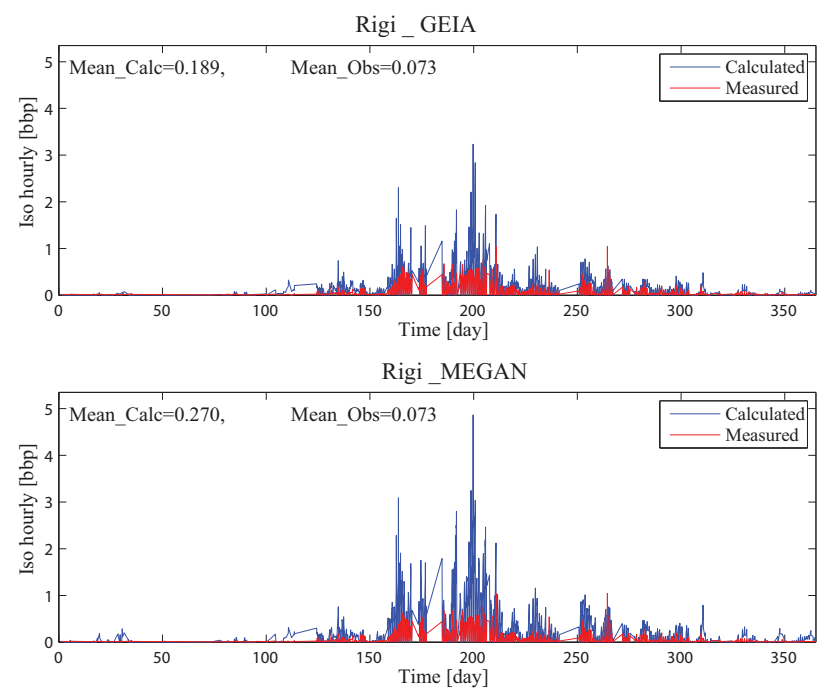

Fig. 10. Validation of the DEHM model results of isoprene concentrations using the MEGAN and GEIA biogenic models in 2006 against measurements for the background station Rigi in Switzerland.

for the Rigi station are compared with those calculated using MEGAN and GEIA. Both models overestimate the observed data, and MEGAN results have a larger difference in this station. Nevertheless, the results are in agreement with Poupkou et al. (2010) concluding an average level of uncertainty within a factor of 4 for isoprene estimations in Europe. In addition, it should also be emphasized that the relatively coarse spatial resolution applied in DEHM in these simulations is not able to well represent the high spatio-temporal variation in the isoprene concentrations. Due to the coarse resolution, the model cannot take into account effects from local sources. The isoprene concentrations can easily vary by a factor of 4 or more within the individual grid cells. However, the purpose of evaluation of isoprene concentrations in 

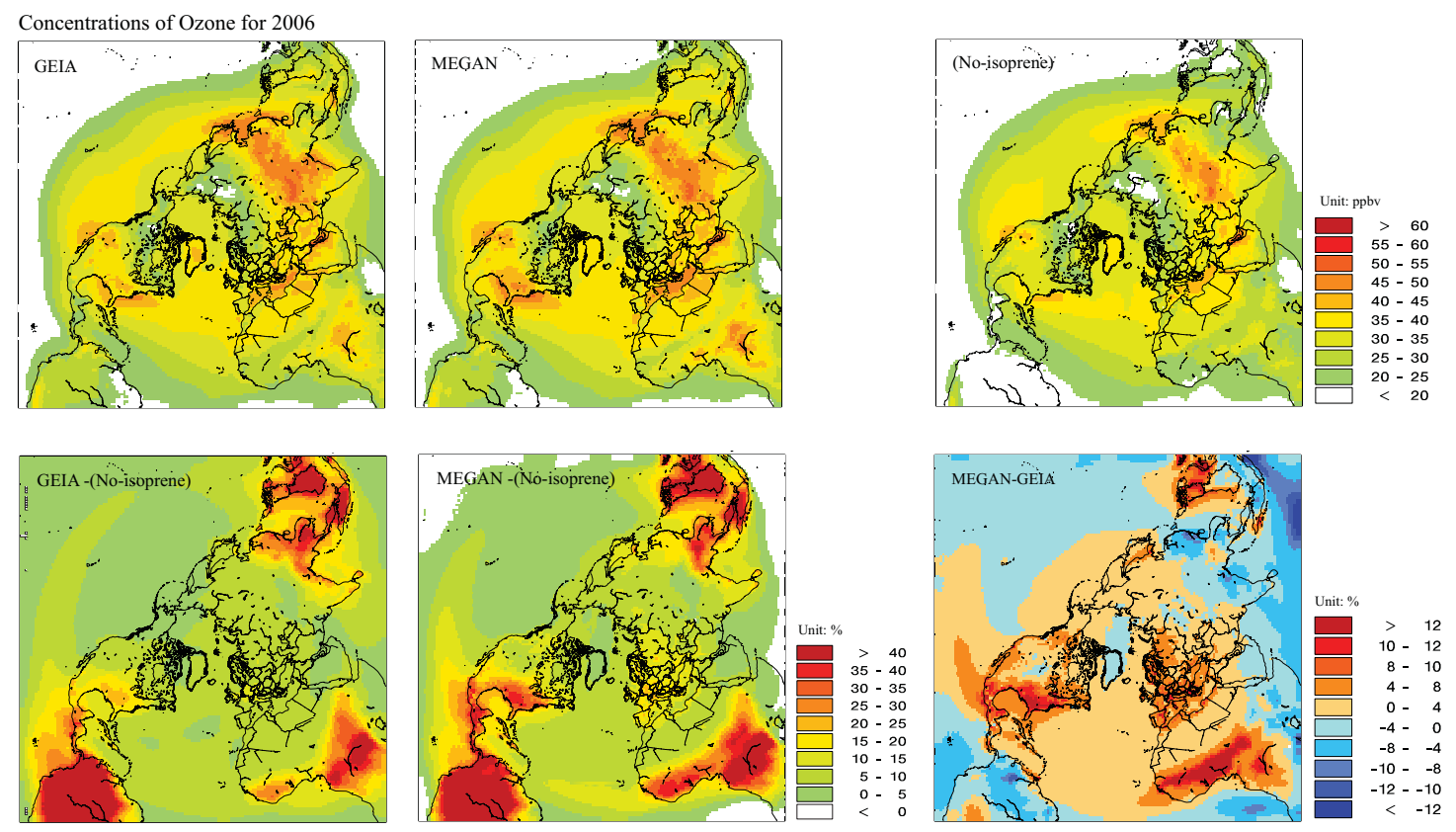

Fig. 11. Ozone concentration (ppbV) simulated by DEHM for the study area using the GEIA (a) and MEGAN (b) isoprene models, and for the biogenic isoprene emissions set to zero (No-Isoprene) (c) in the lowest model layer. Ozone changes due to isoprene estimated by GEIA against No-Isoprene in DEHM (d) and by MEGAN against No-Isoprene in DEHM (e) for 2006. (f) Differences of ozone concentration simulated by DEHM based on the biogenic models of MEGAN and GEIA for 2006.

the present study is to examine whether the model results are in the right order of magnitude.

\subsection{Evaluation of ozone concentrations}

Due to the scarcity of isoprene measurements and its short lifetime, we have also evaluated the DEHM simulations of ozone concentrations, in order to check possible benefits in using the newly developed MEGAN compared to GEIA. We first study the simulated impact of isoprene on ozone concentrations in the lowest model layer, and then evaluate background ozone values against the measurements in Europe and North America.

Biogenic isoprene is one of the key ozone precursors due to the oxidation by hydroxyl radical and nitrate radical in the areas of high anthropogenic emissions (Paulson and Seinfeld, 1992). The gas phase chemistry of isoprene and its byproducts in the DEHM model are presented by Frohn (2004). Hedegaard et al. (2011) discussed the main photochemical processes involved in the formation of tropospheric ozone.

Figure 11 shows the contributions of isoprene to the ozone formation based on the two different models for biogenic emissions. These results are also compared with the case of running the model without the biogenic emissions (hereafter referred to as No-Isoprene) to quantify the contributions from isoprene to the ozone levels in general. The model results show that the highest ozone concentrations occur over industrial or high $\mathrm{NO}_{\mathrm{x}}$ emission regions where they coincide with biogenic emission or biomass burning regions with high isoprene emissions. This can explain the higher ozone concentrations in south-eastern USA, African savannah, and large parts of Asia (e.g. tropical regions) with a maximum annual value of more than $55 \mathrm{ppbV}$ over the densely populated areas.

The comparison of the results based on the two BVOC models with the model results where the biogenic isoprene emissions are set to zero (No-Isoprene) demonstrates that isoprene has a significant impact on the ozone concentrations over land. The isoprene contribution to ozone formation is more than $40 \%$ in the tropics close to isoprene sources. Adding biogenic isoprene with MEGAN also leads to an enhancement of ozone production by up to $15 \%$ in Europe and $30 \%$ in the south-eastern USA, respectively (Fig. 11d).

As mentioned earlier, compared to GEIA, MEGAN estimates higher isoprene emission in the African Savannah, where the additional isoprene increases the ozone production by up to $10 \%$. In contrast, the isoprene emission by GEIA is higher than that of MEGAN in the Amazon region and some locations in East Asia. This results in a higher ozone concentration of around $8 \%$ by GEIA compared to MEGAN in the Amazon. In other parts of the domain, the ozone concentrations simulated using the two biogenic models are quite similar (in the range of 20-35 ppbV). The differences in isoprene impact on ozone concentrations between MEGAN and GEIA are largely consistent with the differences in their isoprene emissions (see Fig. 1). In Europe, the simulated effect 


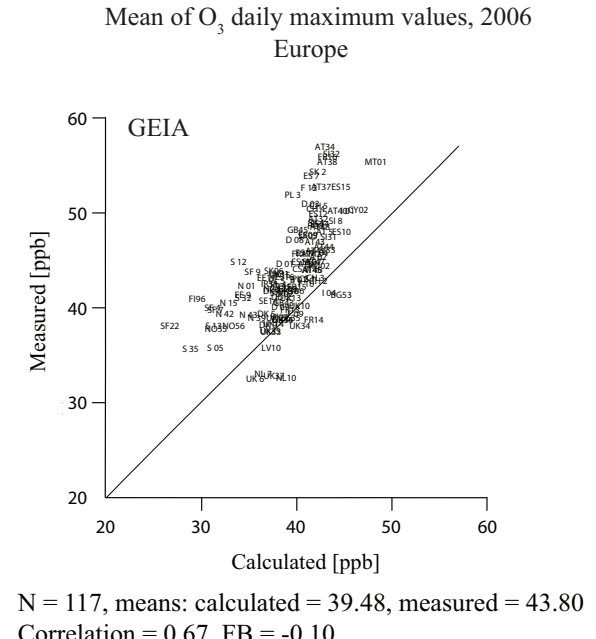

Correlation $=0.67, \mathrm{FB}=-0.10$
Mean of $\mathrm{O}_{3}$ daily maximum values, 2006
Europe

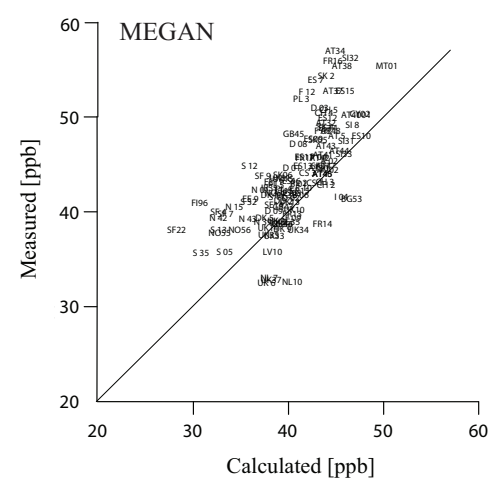

$\mathrm{N}=117$, means: calculated $=40.94$, measured $=43.80$

Correlation $=0.70, \mathrm{FB}=-0.06$

Fig. 12. Comparison of measured and predicted mean values of the daily maximum ozone concentrations with DEHM-GEIA and DEHMMEGAN at 117 rural background stations of EMEP for the year 2006.
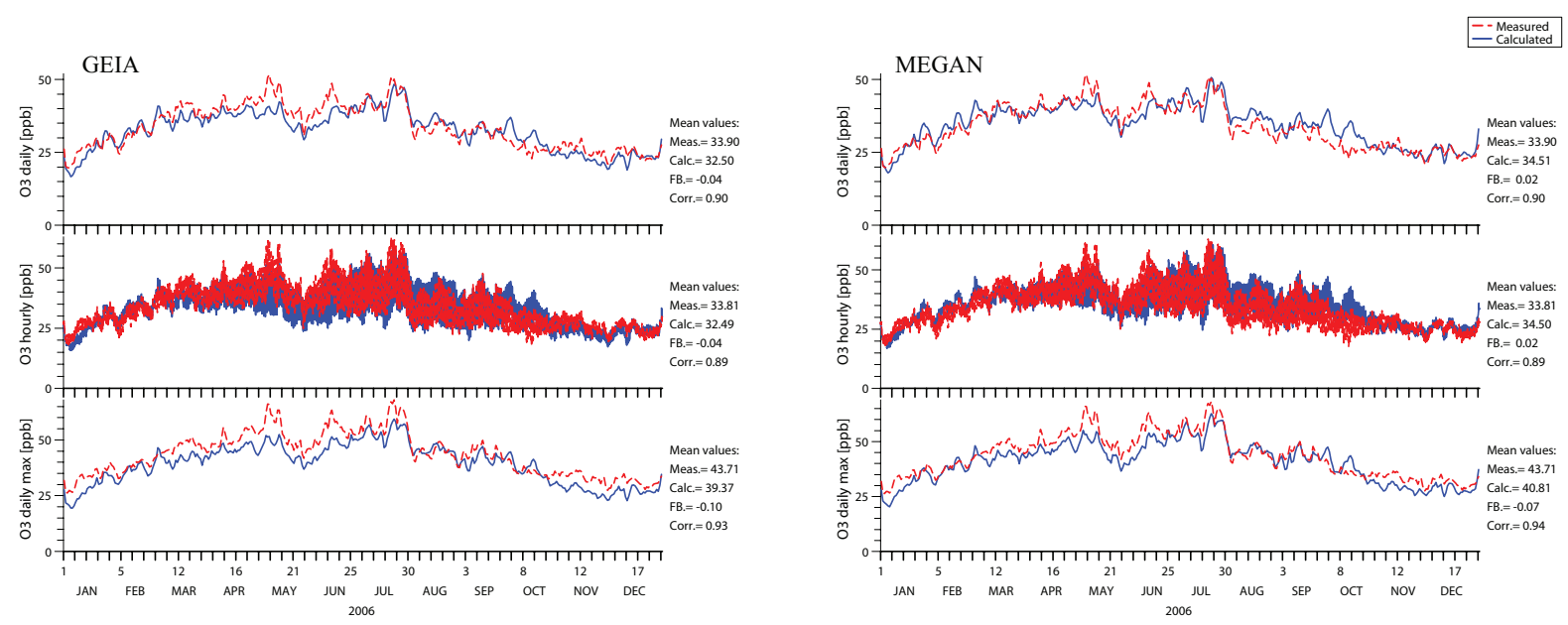

Fig. 13. Evaluation of the DEHM model results for daily mean, hourly and daily maximum ozone concentrations using both the GEIA and MEGAN isoprene emission models for 2006 against available measurements from the EMEP network in Europe.

of isoprene on ozone by MEGAN is up to $4 \%$ more than that by GEIA and in south-eastern USA, exceeds $10 \%$ where the land is covered by some of high isoprene emitting trees such Oak and Eucalyptus (Steinbrecher et al., 2009).

In order to evaluate the indirect effect of using the two different BVOC models, the model simulations of annual mean values of daily maximum ozone concentration for the year 2006 are plotted against measurements obtained from 117 European rural background monitoring sites in Fig. 12. The performance of DEHM is evaluated using the Pearson correlation coefficient and the fractional bias (FB). Results show that DEHM in general performs slightly better with MEGAN (correlation $=0.70 ; \mathrm{FB}=-0.06$ ) than with GEIA (correlation $=0.67 ; \mathrm{FB}-0.10)$. We can conclude from the results that both emission models produce good isoprene estimates on the European scale. As shown in the scatter plots, the results by using the two models are coherent at all stations; for instance, both models slightly overestimate in a few similar measurement sites (e.g. in the United Kingdom, the Netherlands and Bulgaria).

We now compare the time series of ozone concentrations simulated using the two BVOC models with observations. The comparison is shown as a spatial mean of all sites in the region in order to assess the isoprene emission by the two models. In Fig. 13, the results are given for daily means, hourly and daily maxima of ozone concentrations for the year 2006. DEHM performs well in simulating hourly and daily values of $\mathrm{O}_{3}$ (with a correlation up to 0.89 and a small 


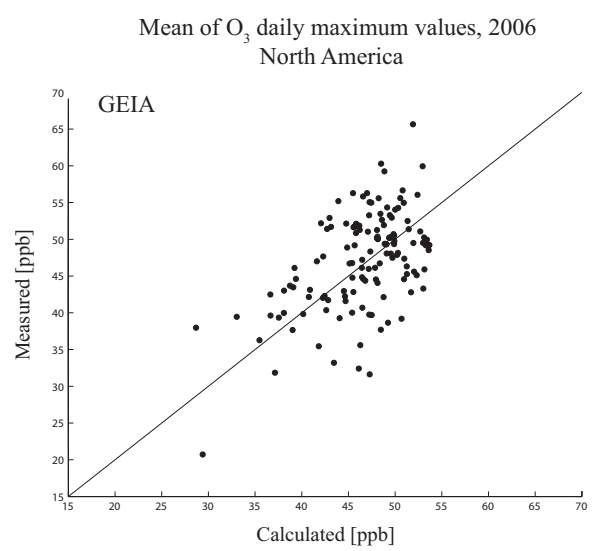

$\mathrm{N}=138$, means: calculated $=46.51$, measured $=47.08$ Correlation $=0.83, \mathrm{FB}=-0.01$

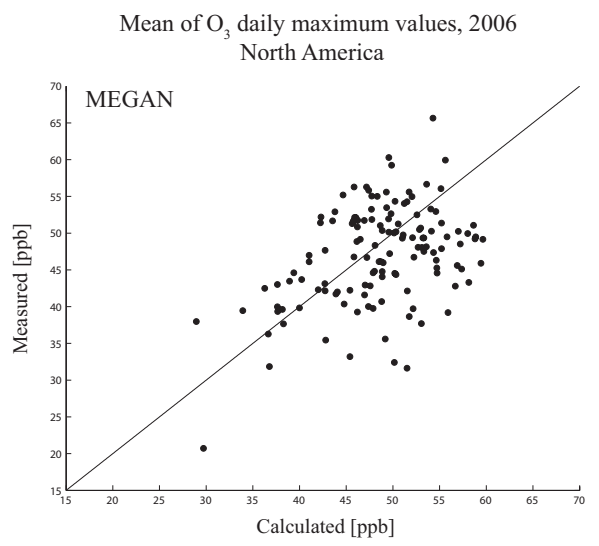

$\mathrm{N}=138$, means: calculated $=48.55$, measured $=47.08$ Correlation $=0.87, \mathrm{FB}=0.03$

Fig. 14. Evaluation of DEHM-GEIA and DEHM-MEGAN results as annual mean values for each measurement station in North America for 2006, compared to available measurements from the Ozone network (taken from the US Environmental Protection Agency database).
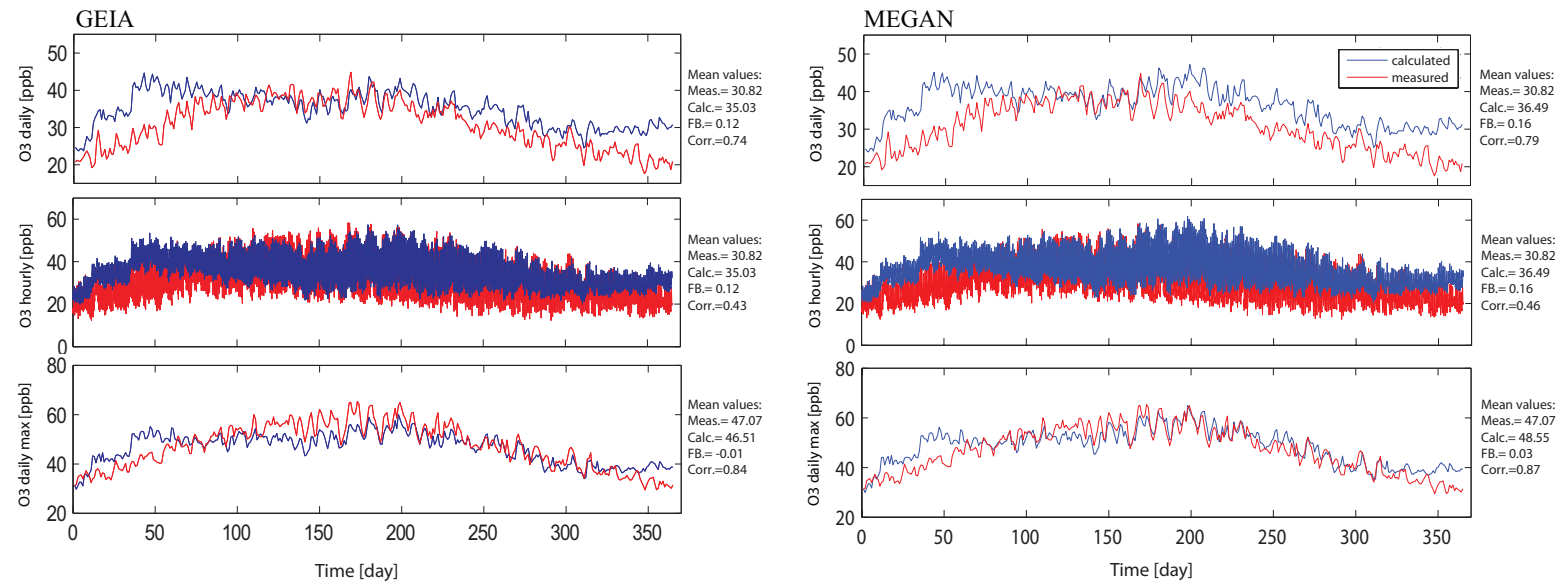

Fig. 15. Evaluation of DEHM results for daily mean, hourly and daily maximum ozone concentrations, using both GEIA and MEGAN for 2006 with available measurements from the Ozone network (taken from the US Environmental Protection Agency database) taken as average values in space over all the measurement stations.

fractional bias) using both models. In addition, the results show that DEHM is able to capture the day-to-day variability of daily mean and maximum concentration of $\mathrm{O}_{3}$. However, the results with using MEGAN for simulation ozone daily maximum over all the sites in Europe show relatively better agreement with observations.

In Fig. 14, the DEHM model results using both MEGAN and GEIA are evaluated for North America as daily maximum values of ozone for the year 2006 compared to available measurements from the Ozone network (taken from the US Environmental Protection Agency). The evaluation of DEHM results of the annual mean values for 138 measurement stations in the United State show a good agreement with observations (with correlation coefficients of up to 0.83 ). However, the DEHM model based on GEIA slightly underestimates the average value of all stations, whereas the DEHM model based on MEGAN overestimates.

The time series of simulated and measured ozone concentrations, as averaged over all the measurement stations in North America for the year 2006, are given in Fig. 15. The results of DEHM using both MEGAN and GEIA do not capture the day-to-day variability of ozone daily mean and maximum concentrations as good as they do for Europe (Fig. 13). This is probably due to the use of a global emission inventory for this area with coarser resolution compared to the EMEP data for Europe. The average values of mean daily and hourly ozone concentrations from DEHM based on both isoprene models are somewhat higher than observations. The MEGAN-based simulation shows the mean values slightly higher than those based on GEIA. Compared to 
ozone mean daily and hourly concentrations, the simulated ozone daily maximum values, using both models, show a relatively good agreement with observations (with correlation up to 0.84 ). Although the simulations using both models overestimate the daily maximum values in the early year, but the MEGAN-based simulation is more successful to capture the large values observed in the summer season.

\section{Conclusions and outlook}

In this paper, a comparison and evaluation of isoprene emissions estimated by the MEGAN and GEIA models has been carried out. The overall goal of the work is to address the issue of better algorithms for biogenic emissions for integrating and application into CTMs on a large scale. In general, the differences in the algorithms result in a $21 \%$ difference in the annual estimate of isoprene emissions in the study area covering the Northern Hemisphere (from $10^{\circ} \mathrm{S}$ to $90^{\circ} \mathrm{N}$ ). Differences between the two models are presented in both the description of model processes and the environmental factors. We found that the most important parameters are the PFT emission factors and the environment activity factors, respectively.

Isoprene measurements for the year 2006 in Europe were used to perform a direct evaluation of the two biogenic emission models coupled in DEHM. Overall, an agreement with the available measurement within a factor of 4 was found for both modelled results in Europe. However, we found that the mean station values of isoprene simulated using the MEGAN model better agree with the mean observed values, compared to those simulated using GEIA. Due to the scarcity of observed isoprene data and the short lifetime of isoprene (making it difficult to compare with a large scale model), an indirect evaluation was made based on measurements of ozone concentration in Europe and North America. DEHM simulations based on the two different isoprene emission models were evaluated against measurements at 117 rural background monitoring sites in Europe and at 138 measuring stations in the US. We found that the performances of DEHM based on both isoprene models are very similar with respect to average daily maximum ozone concentrations in North America whereas using MEGAN results in slightly better agreement than GEIA in Europe.

In general, the results of our study point out the potentially high impact of isoprene on the atmospheric composition and the need for further measurements of isoprene for better evaluations of the emissions and the modelled concentrations of isoprene, especially in the sub-tropical and tropical regions. Future work will be devoted to improve DEHM with emissions and chemistry of other biogenic NMVOCs (e.g. monoterpenes), which also contribute to the air quality (ozone and particulate matter).
Acknowledgements. The authors would like to thank Kirsti Ashworth (Lancaster University) for communication of her results and Associate Marianne Glasius (Aarhus University) for fruitful discussions.

\section{Edited by: M. Kopacz}

\section{References}

Arneth, A., Niinemets, Ü., Pressley, S., Bäck, J., Hari, P., Karl, T., Noe, S., Prentice, I. C., Serça, D., Hickler, T., Wolf, A., and Smith, B.: Process-based estimates of terrestrial ecosystem isoprene emissions: incorporating the effects of a direct $\mathrm{CO}_{2}$-isoprene interaction, Atmos. Chem. Phys., 7, 31-53, doi:10.5194/acp-7-31-2007, 2007.

Arneth, A., Monson, R. K., Schurgers, G., Niinemets, Ü., and Palmer, P. I.: Why are estimates of global terrestrial isoprene emissions so similar (and why is this not so for monoterpenes)?, Atmos. Chem. Phys., 8, 4605-4620, doi:10.5194/acp-8-46052008, 2008.

Arneth, A., Schurgers, G., Lathiere, J., Duhl, T., Beerling, D. J., Hewitt, C. N., Martin, M., and Guenther, A.: Global terrestrial isoprene emission models: sensitivity to variability in climate and vegetation, Atmos. Chem. Phys., 11, 8037-8052, doi:10.5194/acp-11-8037-2011, 2011.

Ashworth, K., Wild, O., and Hewitt, C. N.: Sensitivity of isoprene emissions estimated using MEGAN to the time resolution of input climate data, Atmos. Chem. Phys., 10, 1193-1201, doi:10.5194/acp-10-1193-2010, 2010.

Atkinson, R. and Arey, J.: Atmospheric degradation of volatile organic compounds. American Chemical Society, Chem. Rev., 103, 4605-4638, 2003.

Baker, K.: Peak 8-hr Ozone Model Performance when using Biogenic VOC estimated by MEGAN and BIOME (BEIS), in: 6th Annual CMAS Conference, Chapel Hill, NC, 1-3 October 2007.

Bao, H., Shrestha, K. L., Kondo, A., Kaga, A., and Inoue, Y.: Modeling the influence of biogenic volatile organic compound emissions on ozone concentration during summer season in the Kinki region of Japan, Atmos. Environ., 44, 421-431, 2010.

Brandt, J., Silver, J. D., Frohn, L. M., Geels, C., Gross, A., Hansen, A. B., Hansen, K. M., Hedegaard, G. B., Skjøth, C. A., Villadsen, H., Zare, A., and Christensen, J. H.: An integrated model study for Europe and North America using the Danish Eulerian Hemispheric Model (DEHM) with focus on intercontinental transport, Atmos. Environ., 53, 156-176, 2012.

Christensen, J. H.: The Danish Eulerian Hemispheric Model - a three-dimensional air pollution model used for the Arctic, Atmos. Environ., 31, 4169-4191, 1997.

Curci, G., Beekmann, M., Vautard, R., Smiatek, G., Steinbrecher, R., Theloke, J., and Friedrich, R.: Modelling study of the impact of isoprene and terpene biogenic emissions on European ozone levels, Atmos. Environ., 43, 1444-1455, 2009.

Curci, G., Palmer, P. I., Kurosu, T. P., Chance, K., and Visconti, G.: Estimating European volatile organic compound emissions using satellite observations of formaldehyde from the Ozone Monitoring Instrument, Atmos. Chem. Phys., 10, 11501-11517, doi:10.5194/acp-10-11501-2010, 2010.

Frohn, L. M.: A study of long-term high-resolution air pollution modelling Ministry of the Environment, National Environmental Research Institute, Roskilde, Denmark, 444 pp., 2004. 
Frohn, L. M., Christensen, J. H., and Brandt, J.: Development of a high resolution nested air pollution model - the numerical approach, J. Comput. Phys., 179, 68-94, 2002.

Geng, F., Tie, X., Guenther, A., Li, G., Cao, J., and Harley, P.: Effect of isoprene emissions from major forests on ozone formation in the city of Shanghai, China, Atmos. Chem. Phys., 11, 1044910459, doi:10.5194/acp-11-10449-2011, 2011.

Grell, G. A., Dudhia, J., and Stauffer, D. R.: A description of the fifth-generation Penn State/NCAR mesoscale model (MM5), NCAR/TN-398 STR, Penn State/NCAR, 1994.

Guenther, A., Hewitt, N., Erickson, D., Fall, R., Geron, C., Graedel, T., Harley, P., Klinger, L., Lerdau, M., McKay, W., Pierce, T., Scholes, B., Steinbrecher, R., Tallamraju, R., Taylor, J., and Zimmerman, P.: A global model of natural volatile organic compound emissions, J. Geophys. Res., 100, 8873-8892, 1995.

Guenther, A., Karl, T., Harley, P., Wiedinmyer, C., Palmer, P. I., and Geron, C.: Estimates of global terrestrial isoprene emissions using MEGAN (Model of Emissions of Gases and Aerosols from Nature), Atmos. Chem. Phys., 6, 3181-3210, doi:10.5194/acp-63181-2006, 2006.

Hedegaard, G. B., Brandt, J., Christensen, J. H., Frohn, L. M., Geels, C., Hansen, K. M., and Stendel, M.: Impacts of climate change on air pollution levels in the Northern Hemisphere with special focus on Europe and the Arctic, Atmos. Chem. Phys., 8, 3337-3367, doi:10.5194/acp-8-3337-2008, 2008.

Hedegaard, G. B., Gross, A., Christensen, J. H., May, W., Skov, H., Geels, C., Hansen, K. M., and Brandt, J.: Modelling the impacts of climate change on tropospheric ozone over three centuries, Atmos. Chem. Phys. Discuss., 11, 6805-6843, doi:10.5194/acpd11-6805-2011, 2011.

Lam, Y. F., Fu, J. S., Wu, S., and Mickley, L. J.: Impacts of future climate change and effects of biogenic emissions on surface ozone and particulate matter concentrations in the United States, Atmos. Chem. Phys., 11, 4789-4806, doi:10.5194/acp-11-47892011, 2011.

Lathière, J., Hauglustaine, D. A., Friend, A. D., De NobletDucoudré, N., Viovy, N., and Folberth, G. A.: Impact of climate variability and land use changes on global biogenic volatile organic compound emissions, Atmos. Chem. Phys., 6, 2129-2146, doi:10.5194/acp-6-2129-2006, 2006.

Müller, J.-F., Stavrakou, T., Wallens, S., De Smedt, I., Van Roozendael, M., Potosnak, M. J., Rinne, J., Munger, B., Goldstein, A., and Guenther, A. B.: Global isoprene emissions estimated using MEGAN, ECMWF analyses and a detailed canopy environment model, Atmos. Chem. Phys., 8, 1329-1341, doi:10.5194/acp-81329-2008, 2008.

Olivier, J. G. J., Bouwman, A. F., van der Maas, C. W. M., Berdowski, J. J. M., Veldt, C., Bloos, J. P. J., Visschedijk, A. J. H., Zandveld, P. Y. J. and Haverlag, J. L.: Description of EDGAR Version 2.0: A set of global emission inventories of greenhouse gases and ozone-depleting substances for all anthropogenic and most natural sources on a per country basis and on $1^{\circ}$ $\times 1{ }^{\circ}$ grid, http://www.pbl.nl/en/publications/1996/Description of_EDGAR_Version_2_0, RIVM/TNO report, Bilthoven, RIVM report nr. 771060 002, 1996.

Olson, J.: World ecosystems (WE1.4): Digital raster data on a 10 minute geographic $1080 \times 2160$ grid, Global Ecosytems Database, Version 1.0: Disc A., N. G. D. Center, Boulder CO, Nat. Ocean. Atmos. Admin., 1992.
Paulson, S. E. and Seinfeld, J. H.: Development and evaluation of a photooxidation mechanism for isoprene, J. Geophys. Res., 97, 20703-20715, 1992.

Pfister, G. G., Emmons, L. K., Hess, P. G., Lamarque, J. F., Orlando, J. J., Walters, S., Guenther, A., Palmer, P. I., and Lawrence, P. J.: Contribution of isoprene to chemical budgets: a model tracer study with the NCAR CTM MOZART-4, J. Geophys. Res., 113, D05308, doi:10.1029/2007JD008948, 2008.

Pierce, T., Geron, C., Bender, L., Dennis, R., Tonnesen, G., and Guenther, A.: Influence of increased isoprene emissions on regional ozone modelling, J. Geophys. Res., 103, 25611-25629, 1998.

Pouliot, G. and Pierce, T. E.: Integration of the Model of Emissions of Gases and Aerosols from Nature (MEGAN) into the CMAQ Modeling System, 18th International Emission Inventory Conference, Baltimore, Maryland, 14-17 April 2009.

Poupkou, A., Giannaros, T., Markakis, K., Kioutsioukis, I., Curci, G., Melas, D., and Zerefos, C.: A model for European Biogenic Volatile Organic Compound emissions: Software development and first validation, Environ. Modell. Softw., 25, 1845-1856, 2010.

Schultz, M. G., Heil, A., Hoelzemann, J. J., Spessa, A., Thonicke, K., Goldammer, J., Held, A. C., and Pereira, J. M.: Global emissions from wildland fires from 1960 to 2000, Global Biogeochem. Cy., 22, GB2002, doi:10.1029/2007GB003031, 2008.

Souza, L. S. D., Landau, L., and Pimentel, L. C.: Air quality photochemical study over Amazonia area, 13th Conference on Harmonisation within Atmospheric Dispersion Modelling for Regulatory Purposes, Paris, France, 1-4 June 2010.

Steinbrecher, R., Smiatek, G., Köble, R., Seufert, G., Theloke, J., Hauff, K., Ciccioli, P., Vautard, R., and Curci, G.: Intra- and inter-annual variability of VOC emissions from natural and seminatural vegetation in Europe and neighbouring countries, Atmos. Environ., 43, 1380-1391, 2009.

Steiner, A. L., Cohen, R. C., Harley, R. A., Tonse, S., Millet, D. B., Schade, G. W., and Goldstein, A. H.: VOC reactivity in central California: comparing an air quality model to ground-based measurements, Atmos. Chem. Phys., 8, 351-368, doi:10.5194/acp-8351-2008, 2008.

Strand, A. and Hov, O.: A 2-Dimensional Global Study of Tropospheric Ozone Production, J. Geophys. Res., 99, 22877-22895, 1994.

Tsigaridis, K. and Kanakidou, M.: Global modelling of secondary organic aerosol in the troposphere: a sensitivity analysis, Atmos. Chem. Phys., 3, 1849-1869, doi:10.5194/acp-3-1849-2003, 2003.

Warneke, C., de Gouw, J. A., Del Negro, L., Brioude, J., McKeen, S., Stark, H., Kuster, W. C., Goldan, P. D., Trainer, M., Fehsenfeld, F. C., Wiedinmyer, C., Guenther, A. B., Hansel, A., Wisthaler, A., Atlas, E., Holloway, J. S., Ryerson, T. B., Peis chl, J., Huey, L. G., and Hanks, A. T. C.: Biogenic emission measurement and inventories determination of biogenic emissions in the eastern United States and Texas and comparison with biogenic emission inventories, J. Geophys. Res., 115, D00F18, doi:10.1029/2009JD012445, 2010.

Wiedinmyer, C., Guenther, A., Duhl, T., Sakulyanontvittya, T., Chung, S., and Fast, J.: MEGAN and WRF-CHEM, 9th Annual Ad-Hoc Meteorological Modelers Meeting, Boulder, Colorado, 26-27 June, 2008. 